\title{
In Memoriam: The Experience of Eulogizing a Loved One
}

Paul Sopcak, Comparative Literature Program, University of Alberta

Email: psopcak@ualberta.ca

\section{Abstract}

Whether the "call" to write a eulogy comes when we learn of our loved one's death or shortly after, it comes when we may not yet be able to mourn-let alone make a declaration. The death of a loved one may alienate us from the world and from the sense of self that rests on our daily living in the world and with others. It may "individualize us down to ourselves" by throwing us into a world utterly devoid of meaning and anchors. Paradoxically, from this "nothing," a call may usher forth demanding us to take a stand on our loved one's death and ultimately on our being here. Trying to avoid hearing this call when threatened by the nothingness and worldcollapse that a loved one's death brings may be the most natural response. But what happens when we are asked to write a eulogy? Can we ignore the call or is it itself inextricably intertwined with our mourning and precisely that which begs to be expressed? This paper describes the experience of eulogizing a loved one as an encounter with the mortality of words, as listening to silence, and as addressing the deceased-without bathos or pathos.

\section{The Call}

But what I thought impossible, indecent, and unjustifiable, what long ago and more or less secretly and resolutely I had promised myself never to do... was to write following the death, not after, not long after the death by returning to it, but just following the death, upon or on the occasion of the death, at the commemorative gatherings and tributes, in the writings "in memory" of those who while living have been my friends, still present enough to me that some "declaration" ... would seem at that moment completely unbearable. (Derrida, 2001, pp. 49-50)

While trying to understand the pain and grasp my own and my loved ones' impermanence, the phone call comes, "Kris can you please write the eulogy?" I don't know how I feel, but I want to simply say "No". I want to forego my duty and privileged spot in the family and just refuse. My chest is heavy and imagining writing the eulogy puts unbearable pressure on it. Without letting my family members know how unstable and crushed I feel, I accept what seems like an obligation. I have a week. 
Upon learning of the death of a loved one, some seek solace in solitude or distraction. Others seek comfort in communal mourning, gathering with friends to tell and retell all the life-shaping experiences shared with the person who is no longer, who has died, who is dead. The memories grow paler, increasingly transfiguring into stories with each retelling, and yet we may seek the soothing effect that the patterns of narration bring. The death of someone we love may leave us paralyzed in overwhelming sorrow and turn the world into a strange and uncanny place. Our world may become vertiginous and we may face not only the loss of a loved one, but also an acute sense of finitude in general. Standing on the ruins of a non-retrievable sense of herself and the world, the young woman in the example above chooses to act resolutely and agrees to write "upon or on the occasion of the death." Whether the "call" to write a eulogy comes when we learn of our loved one's death or shortly after, it comes when we may not yet be able to mourn, let alone make a “declaration,” as Derrida puts it.

\section{Writing a Eulogy Means Experiencing the Mortality of Words}

It's been days since Papa passed and I can't find words. It is as if the words died with him. I avoid my computer and journal. I hate being alone. Sitting anywhere in silence triggers an onslaught of memories. Merely peering through the window at these memories brings such intense pain that I have to turn away and close the drapes tightly. The moments between sleep and waking are particularly difficult because in those quiet moments the memories find me: uninvited, unannounced, demanding my attention.

The death of a loved one may leave a paralyzing emptiness and threaten the coherence of our world and who we are. In the face of this threat, some may find shelter in the everyday flow of life and let time do "the work of mourning". When the drapes blow open, catching us off guard, and memories intrude, some may seek to lose themselves in what Heidegger termed the "idle talk of the "they"' (1962, p. 322) to stave off the implications of (the) death and the vertiginous void it throws us into. It is when, alone and in silence, that the rawness of our pain, our broken sense of self and world, and the acute sensation of finitude may intrude and carry us off. Strangely, however, it is from this very silence that a call may usher forth demanding our attention. But who is the caller? What calls? Heidegger says that

The caller is unfamiliar to the everyday they-self; it is something like an alien voice. What could be more alien to the "they", lost in the manifold "world" of its concern, than the Self which has been individualized down to itself in uncanniness and been thrown into the "nothing"? ... The call does not report events; it calls without uttering anything. The call discourses in the uncanny mode of keeping silent. And it does this only because, in calling the one to whom the appeal is made, it does not call him into the public idle talk of the "they", but calls him back from this into the reticence of his existent potentiality-for-Being. (1962, pp. 321-322)

The death of a loved one may alienate us from the world and from the sense of self that rests on our daily living in the world and with others. It may "individualize us down to ourselves" by throwing us into a world utterly devoid of meaning and anchors. Paradoxically, from this 
"nothing," a call may usher forth demanding us to take a stand on our loved one's death and ultimately on our being here. Trying to avoid hearing this call in the threat of nothingness and world-collapse that a loved one's death brings may be the most natural response. So, we gather, cry, tell stories, laugh and touch to fill the void. Through our communion and storytelling we reestablish a sense of continuity and order into our fragile world. But what happens when we are asked to write a eulogy? Can we ignore the call that ushers forth from the silence or is it itself inextricably intertwined with our mourning and precisely that which begs to be expressed?

\title{
Writing a Eulogy Means Listening to the Silence
}

\begin{abstract}
A few days before the service, I arrive at the point where I cannot practice avoidance any longer. I tap on my keyboard and create a new file called, "Papa's eulogy". It seems as though my whole being is resisting but anxious to begin all at once. Sacred memories with Papa: receiving my first flower, having my first dance, riding my first horse, drinking my first cup of coffee, and taking my first camping trip. I cry. Each memory is accompanied by more tears and a deeper understanding of the many ways in which Papa has shaped my life. My life. I begin to get a sense of the magnitude of the task ahead of me. How can I possibly capture my grandpapa, a great, great man, in a few pages of a speech? Further, how can I write it for others when I can only access my experience? I've had memories with Papa for thirty years. What about my father who has rich memories spanning fifty-five years or Papa's brother with memories over eighty years?
\end{abstract}

In silence and solitude the "sacred" and life-shaping memories that tie us to the loved one may find us. But now, these recalled events perhaps for the first time gain their full meaning and magnitude. They stand out from the horizon of death. Ironically, their full beauty is revealed when the life has irretrievably left the relation from which they came forth. It is against the horizon of finitude that the fragility and wonder of our experiences become tangible. And we may realize how they carry forward into the future, how they attune us toward the world and future experiences: A faint echo of Papa handing the young woman her first flower in every flower received since; every coffee carrying a taste of Papa initiating her into a world that comes alive through coffee.

However, it is within the context of this newly emerging, felt understanding (Gendlin, 1962) of how much our world and our sense of self was built upon the experiences we shared with the deceased loved one that we may also begin to realize the paucity of words to express the intricacy, richness, and consequences of our relation on the one hand, and the impact of his or her death on the other. In fact, the realization of this inadequacy of words might be accompanied by a feeling of reluctance to write the eulogy.

Connecting to my experience of Papa should have been a catalyst for writing, but as my memories of him unravel, I want to keep them to myself. I want to hold my memories close in fear that telling them will take away their sacredness. Will others really understand Papa and sense him when I tell them the story of our last golfing trip? How can they? How will they see the twinkle in his eye, be wrapped in his grateful spirit, hear his loving lessons, and share in his joyful laughter? They can't. 
They will never fully understand and despite the most eloquently chosen words, there will always be a gap between my experience and the description of it. The screen on my computer is still blank. I am stuck. Caught between needing to write something and wanting to keep the sacredness of the memories to myself.

There is a certain irony in the young woman's testimonial. In telling of her grandpapa she is already writing the eulogy that she cannot write. We may sometimes be struck with the incredible eloquence of a eulogy written for a loved one; how someone as if from nowhere will find words reflecting a depth that is truly astounding and moving.

It thus seems that writing our relation to and loss of our relation to the loved one that died, or bringing it to expression, involves capturing from the flow of life and framing some aspect or experience of it by arresting the flow; by stealing, as it were, from its fullness. Merleau-Ponty describes this as follows: "For to name a thing is to tear oneself away from its individual and unique characteristics to see it as a representative of an essence or a category ...” (1962, p. 204).

Every memory of our loved one brought to expression carries with it this possible sacrilege and yet, we sense the fragility of our memories; the corrosion of time gnawing at those memories that we selfishly hold back or fail to bring to expression. We can no longer dip back into and draw from the well of this particular relation. At times, however, we may pause in our writing and hearken if maybe from the silence an echo of our loved one's voice will come forth to give us guidance.

Such may be the undercurrents of the eulogist's predicament of needing to write and wanting to keep the sacredness of the memories to oneself. Of having to write and being unable to writethe words will not come or fail to express what we feel they must. Of having to draw from a silence that is primordial and tears at the roots of one's understanding of world and self, a silence that may bring an epiphany of finitude.

The eulogist who draws from this primordial silence to render, with her or his whole being, the lost loved one this last service must, it seems, come to terms with the inevitability of not only the fragility and finitude of life, but also with the fact that expression always has this double aspect to it: It may bring forth something hitherto concealed; yet simultaneously it dries the well it springs from.

These challenges may invite questions that intrude upon the person writing a eulogy: "Why should I be the one to write the eulogy? How could I ever do justice to the loved one who died? The memories I cherish are MINE. They are no one's business!” Pascale-Anne Brault and Michael Naas ask themselves and the reader: "To whom or what are we responsible in mourning? To the friend him- or herself? To his or her words? His or her memory? What is the best way of remaining faithful” (2001, p. 22)?

\section{To Write a Eulogy is to Write with an Audience in Mind}

I loved my mother but I also harbored anger, resentment and bitter hurt towards her. I want to acknowledge that she was hard to love. Yet, I also want to say that she was deeply worthy of love. I want people to know that her life was filled with struggles. I want my brother and sisters to feel a little love, a little gentleness for their mother. I want to remind them that she had loved dad, that she was capable of that kind of passionate loving. In writing, I will attempt to quell the storm and try to 
intercede for her. I want to commit good things to memory, mine and theirs. I want to be noble and admired for a good job of honoring her.

The intended audience of someone writing a eulogy may be multi-faceted. One may be writing, not only for those who will be present at the funeral but also for oneself, for the relationship shared, and perhaps, mostly for the person who has died. Each of these audiences may place very different demands on the writer. Some eulogists may want "to be noble and admired for a good job of honoring" their loved one, while at the same time remaining sensitive to the fact that the relationship others had with the person who has died might be very different from their own. The person writing a eulogy may ask: "How can I remain truthful to myself and my relation with the person who died, and at the same time reach out to those who will be present at the funeral with a eulogy that expresses aspects of their loss and their relationships?”

With specific listeners in mind, a eulogist may take it upon him- or herself to "intercede" for the dead with words the deceased person may never have been able to utter; to let their love speak through the eulogy. A eulogist may also speak in defense of what the audience may perceive as the deceased's shortcomings by attempting to "commit good things to memory." Derrida has described this as the eulogist's effort to produce the "final evaluation" (2001, p. 50). Speaking on the occasion of the death of a loved one may thus put the eulogist in that singular situation in which the addressee is not yet fully departed, but not wholly with us anymore either. It is a fulcrum in passing time that brings a life, a web of relations and memories to a close, and the eulogy may be crucial in setting the tracks for how the mourned is committed to the audience's memory and future discourse.

Paradoxically, the person who has died may remain closest to the eulogist since his or her death, may intrude into her thoughts and dreams and command to be spoken to. This presence, however, is pervaded by the painful reality of the loved one's absence. This wrestling with the absence of and urge to address the lost friend or family member one last time may find expression in the eulogist's use of the second person "you," as in the example below:

As I read the words I am writing, the eulogy seems too sentimental, as if I am deliberately trying to evoke tears. Then again, I suppose I do want tears.

I read again what I have written so far, to myself out loud: "It is impossible to think of Chris, beloved brother ..." Halfway through the first sentence, as I reach his name, I choke up, my eyes overflowing with tears and I cannot go on.

I compose myself and begin again. And again, until I haltingly make it all the way through. Some passages are harder than others to speak through. I put the eulogy aside until tomorrow.

The next morning, I read it over again, "It is impossible to think of Chris, beloved brother, uncle, friend, mentor, and traveling companion, without a smile ... Chris so delighted in the simplest and finest of pleasures, and ..." I suddenly realize what needs to be changed. It is to Chris I want to say these things, first, foremost and directly. I quickly search through the document and switch Chris from third- to second-person: "It is impossible to think of you, Chris, beloved brother, uncle, friend, mentor, and traveling companion, without a smile, calling to mind the always-ready sparkle in your eye, your fierce fondness for and devotion to family and friends, and your infectious love of life, story and laughter. You so delighted in the simplest and finest of pleasures, and we so delighted in your..." I feel more 
satisfied; a little closer to what I want to say to him, but also to my aunt, and their son.

The eulogist may read out loud to him- or herself the words hesitantly written, gauging the effect they will have on the audience. Like a painter who stands back to take in the work, the eulogist may take a step back from a tentative beginning and feel whether it expresses what urges to come forth. Yet, the same words may at times close the distance the eulogist needs to write and pull him or her back to the pain of the loss. Tears, violent sobs, and feeling crushed under unbearable pressure may force an interruption of the writing.

When writing is possible, the weighing of words becomes a weighing against something. There may be a sense in which the eulogy is groping toward an expression of a felt understanding of what the loss has shored up: the sadness, the heightened sense of our love for the lost friend or family member, the keen sense of finitude, our broken sense of self, etc. Gendlin describes this phenomenon as a "lifting out":

Thus feeling must be understood as implicitly meaningful, and as changing when there are steps of "lifting out," steps of explication or articulation. To articulate is to live further. To go back into how one has been living is a forward-moving step. ...We don't want to think that the words were in the feeling in the sense that pebbles are in a box. How language relates to feeling and living needs re-thinking. But it is clear that just as in living [one] uses words as an inherent part of living, so also does the feeling-understanding already have the power to guide speech, even though, at first it is only felt. (1978-1979, p. 51; Gendlin’s emphasis)

Entering into such a "dialogue with oneself” (Arendt 2007, p. 70) may at times seem impossible or become too painful in the face of the loss. The eulogist may falter or find the words fleeing rather than finding him or her. When this happens, he or she may turn for guidance to what have been established as customary characteristics of a eulogy. Such a "template" may prove a safe harbor, perhaps especially in the beginning, when the eulogist may be lost in a sea of conflicting emotions, memories, and intentions. But then, while building the eulogy around this scaffolding, he or she may find that the norms and expectations increasingly get in the way of an authentic response to the particular situation and in the way of what urges to come forth.

\section{Eulogizing Means Avoiding Bathos and Pathos}

How will I speak in a way that helps point to the mystery instead of colonizing this event for the sake of my beliefs; for the sake of my suffering; or pain or for the sake of some kind of fantasy? A birthday party with Jesus ... Lots of eulogies in Protestantism these days are done around celebrations. I could give a damn about celebrations. Funerals are not about celebrations ... way too quick. I can't be sentimental either, though. It's too easy to speak to some kind of fantasy and ignore the reality. None of that properly engages the dignity of Rob. Sentimentality would be a form of cynicism, just like fantasy. It fails to look at the extraordinary wonder of Rob's life ... and that it has ended. How will I speak in a way that helps open that instead of close it? How can I not assume, how can I hold the parts of Rob together 
and particularly his struggle, his vivid struggle. I will try to pull life from death.

The ground of the many "fantasies" around death and afterlife referred to above may well lie in the unimaginability of non-existence and the heightened urgency to narrativize around and beyond the limits of imagination. Stranded on this "Shore of Nothingness" (Tsur 2003), some eulogists may seek footing in their personal loss and their own relation with the dead loved one to spin their narrative around these axes. Others' eulogies may express the attempt to make sense of the loss by presenting it as an affirmation of preconceived notions around existential questions regarding death, love, and life; perhaps as part of an encompassing religious outlook.

What, however, is the eulogist in the preceding example after? What needs more time than is allowed by celebrations on the occasion of death? How could a sentimental funeral speech be a form of cynicism?

The eulogist may find that his or her speech, if it is to be sincere, must to some extent express their personal grief and anguish at the loss. Yet, he or she may also find that it must reach beyond the egocentric to avoid being sentimental. This may mean resisting the wave of self-pity that the death of a loved one may trigger, the temptation to wallow in the grief and let the reigns of a deeply-rooted nostalgia loose in light of which the pain of this particular loss stands in for or fills the vacuum of a generic Weltschmerz.

Likewise, some may want to avoid having their eulogy express a coming to terms with or making sense of the loved one's death solely within a ritualized and perhaps religious worldview. Here again, rather than "lifting out" the singular significance of this particular death, the eulogy may prematurely close off the possibility of mourning. Thus, instead of producing a "final evaluation" (2001, p. 50), as Derrida puts it, the eulogist may seek to call forth in him- or herself and the audience an opening up to "the extraordinary wonder of" the loved one's life. Here the life and death of our loved one does not stand in for or represent the wonder and mystery of life and death in general, but rather brings it to presence in its particularity and may require abandoning all preconceived notions and confronting this death as if it were the first. What such a eulogy demands of its author may be akin to what Merleau-Ponty has to say about aesthetic expression:

The process of expression, when it is successful, does not merely leave for the reader and the writer himself a kind of reminder, it brings the meaning into existence as a thing at the very heart of the text, it brings it to life in an organism of words, establishing it in the writer or the reader as a new sense organ, opening a new field or a new dimension to our experience. ...Aesthetic expression confers on what it expresses an existence in itself, installs it in nature as a thing perceived and accessible in itself, installs it in nature as a thing perceived and accessible to all, or conversely plucks the signs themselves - the person of the actor, or the colours and canvas of the painter-from their empirical existence and bears them off into another world. (1962, p. 212)

To bring forth in him- or herself and the audience a sense of the loved one's death "as a new sense organ" may be the goal of some eulogists; a goal that draws into the distance as it is approached. There perhaps remains a feeling of inadequacy before such a gigantic task. Here too, time will be the mover, weighing down but then providing relief as the day of the funeral arrives and the eulogist must come to terms with what, however imperfect, he or she has written. 
Rereading my drafts and knowing the masterpiece I am attempting to create, my critical perfectionist has much to say. Nothing seems enough or quite right. The hardest part is feeling satisfied that I honored Papa and his life. Nevertheless, time allows me no choice but to accept what has been written. I send it off to my dad and he asks if I want the officiator to deliver the eulogy. What? Someone else speak my words? Will separating myself from them destroy their sacredness? Do I need to speak to breathe life into the words and make them genuine?

\section{Delivering the Eulogy}

After making peace with the forever incomplete manuscript, another challenge and decision may face the author of a eulogy. Will he or she deliver it on the day of the funeral or will some "professional" speak what was wrung from their worry, sweat, and tears? How genuine will the words be if delivered by an officiator, the young woman in the preceding example asks. As described by Merleau-Ponty above (and supported by the tradition of literature), it seems that a text itself may very well bring "the meaning into existence as a thing at the very heart of the text” (1962, p. 212) and thus provide the possibility of an authentic encounter. Some may have no difficulty parting with their eulogy or they may quite simply recognize that they would break down while delivering this farewell and declaration of love to an audience of the loved one's friends and family. After their struggle to bring forth a eulogy that is genuine and sincere, they may look forward to hearing their words spoken and to let them have their effect without risking the danger of a pressure to perform, to not break down midway through the speech, ruining this singular moment.

Yet others may find the eulogy complete only in their own personal delivery of it. They may be doubtful of the power of words alone, separated from their source, expressing their thoughts and feelings. And when the day arrives to say goodbye, they may have anticipated some of the challenges and taken some practical precautions. In their rehearsal, they may have found, for instance, the passages in their eulogy, which were particularly difficult to deliver and planned to pause before them to breathe deeply and refocus before confronting the next paragraph. Or they may have quite simply used a font large enough to decipher through their blurred vision and have tissues ready to wipe away their tears. A "backup” orator may have been chosen to take over when the eulogist fails to get through his or her text.

This is it. Great! We're only halfway through Bach's "Mache Dich mein Herze rein" and I'm already sobbing. "World Expire!" How well the aria captures my grief. O.K., pull yourself together and speak clearly when you get up there, for Christ's sake. This is it, my goodbye to you. Don't mess it up!

\section{References}

Arendt, H. (2007). Über das Böse: Eine Vorlesung zu Fragen der Ethik. Munich: Piper Verlag. Brault, P. A. and Naas, M. (2001). Editor’s introduction: To reckon with the dead: Jacques 
Derrida’s politics of mourning. In P.-A. Brault \& M. Naas (Eds.), The work of mourning / Jacques Derrida (pp. 1-30). Chicago: The University of Chicago Press.

Derrida, J. (2003). The work of mourning / Jacques Derrida. P. A. Brault \& M. Naas, Eds. Chicago: The University of Chicago Press.

Gendlin, E. (1962). Experiencing and the creation of meaning. New York: Free Press, Macmillan.

Gendlin, E. (1978-79). Befindlichkeit: Heidegger and the philosophy of psychology. Review of Existential Psychology and Psychiatry: Heidegger and Psychology, 16(1-3), 43-71.

Heidegger, M. (1962). Being and time. (J. Macquarrie \& E. Robinson, Trans.). New York: Harper \& Row.

Merleau-Ponty, M. (1962). Phenomenology of perception. New York: Routledge \& Kegan Paul.

Tsur, R. (2003). On the shore of nothingness: space rhythm and semantic structure in religious poetry and its mystic-secular counterpart. A study in cognitive poetics. Exeter: Imprint Academic. 